\title{
Different Survival Benefit of Osimertinib in Different Sequences: A Real-World Outcome of Osimertinib Treatment in Pretreated T790M-Positive Advanced NSCLC in Taiwan
}

Chin-Chou Wang ( $\nabla$ ccwang5202@yahoo.com.tw)

Kaohsiung Medical Center: Chang Gung Memorial Hospital Kaohsiung Branch https://orcid.org/00000003-2932-751X

Chien-Hao Lai

Chang Gung Memorial Hospital Kaohsiung Branch Huang-Chih Chang

Chang Gung Memorial Hospital Kaohsiung Branch

Chia-Cheng Tseng

Chang Gung Memorial Hospital Kaohsiung Branch

Kuo-Tung Huang

Chang Gung Memorial Hospital Kaohsiung Branch

Meng-Chih Lin

Chang Gung Memorial Hospital Kaohsiung Branch

Research article

Keywords: Osimertinib, EGFR T790M mutation, progression-free survival, overall survival, disease control rate.

Posted Date: June 8th, 2021

DOI: https://doi.org/10.21203/rs.3.rs-554803/v1

License: (c) (i) This work is licensed under a Creative Commons Attribution 4.0 International License. Read Full License 


\section{Abstract}

Background: To investigate the relationships among the clinical characteristics, different EGFR-TKIs, and osimertinib treatment in different treatment lines.

Methods: We retrospectively screened a total of 3807 patients diagnosed between 2013 and 2019 at Kaohsiung Chang Gung Memorial Hospital. Furthermore, 98 patients after re-biopsy or liquid with EGFR T790M mutation who received osimertinib were enrolled for analysis.

Results: Among all 98 patients, the median PFS of those who received osimertinib therapy was 10.48 months, and the median OS of those who received osimertinib therapy was 42.21 months. The OS of those who received osimertinib therapy after previous gefitinib, afatinib, or erlotinib therapy was 87.93 , 49.00 , and 42.00 months, respectively $(P=0.006)$. There was a significant difference in disease control rate between those who received osimertinib treatment after previous chemotherapy (Group $A$ ) or immediately following EGFR-TKI therapy (Group B) (93.3\% vs. $77.4 \%, P=0.029)$. There was also a significant difference in PS between those who received osimertinib as a second-line treatment and those who received it as a third-line treatment (10.83 vs. 17.33 months, $P=0.044)$. In addition, COPD tended to be a poor prognostic factor for PFS and OS.

Conclusion: In this retrospective real-world analysis, it was determined that pretreatment with gefitinib and previous chemotherapy could affect the treatment outcomes of NSCLC patients treated with osimertinib. Furthermore, COPD tended to a poor prognostic factor for PFS and OS in such patients.

\section{Background}

Lung cancer is the cancer with high prevalence and high mortality worldwide. Non-small cell lung cancer (NSCLC) accounts for about $80 \%-85 \%$ of all cases of lung cancer. According to the results of history and molecular biology tests, the treatment of lung cancer is personalized. Among various target oncogenes, epidermal growth factor receptor (EGFR) mutations are earliest and key genetic drivers of NSCLC. EGFR mutations are present in $10 \%$ of the Caucasian population, but in $40 \%-50 \%$ of the Asian population, including the population of Taiwan.[1-3] Previous clinical trials and studies have shown that compared with platinum-based chemotherapy regimens, EGFR-tyrosine kinase inhibitors (TKIs) produce better response rates and fewer adverse reactions. The objective response rate of the first and second generation EGFR-TKI is around between $60 \%$ and $80 \%$, and the median progression-free survival (PFS) duration is around 10 to 13 months.[4-12] When these patients experienced disease progression (PD), newly acquired resistant EGFR p.Thr790Met (T790M) point mutations were developed in about 50\%-70\% of patients.[13-15] These acquired resistant mutations enhance the binding affinity of adenosine triphosphate to the EGFR kinase domain, thereby reducing the efficacy of the first and second generation EGFR-TKIs.

Osimertinib, a third-generation EGFR-TKI, was designed to and is active in non-small cell lung cancers harboring the EGFR T790M mutation.[16-19] Published reports of clinical trials have shown that 
osimertinib has better efficacy in patients who undergo disease progression after the first and secondgeneration EGFR-TKI treatments.[16-19] AURA 3, a phase 3 clinical trial regarding osimertinib, also reported an better PFS associated in osimertinib compared to standard chemotherapy for NSCLC patients with acquired T790M mutations.[19] Therefore, re-biopsy or liquid biopsy is needed to prove the mechanism of acquired drug-resistance when EGFR mutations patients with PD after EGFR-TKI treatment.

In this study, we evaluated the response rate, progression-free survival (PFS), and overall survival (OS) of patients who received osimertinib treatment after a first-generation EGFR-TKI (gefitinib or erlotinib) or a second-generation EGFR-TKI (afatinib). The main objective of this study was to investigate the relationships among the clinical characteristics, different EGFR-TKIs, and osimertinib treatment in different treatment lines.

\section{Methods}

The study retrospectively screened a total of 3807 patients who were diagnosed with pathologicallyconfirmed lung cancer between January 2013 and April 2019 at Kaohsiung Chang Gung Memorial Hospital. Among these patients, there were 879 patients with inoperable EGFR mutation-positive adenocarcinoma who had received a first-generation EGFR-TKI (gefitinib or erlotinib) or a secondgeneration EGFR-TKI (afatinib) as the first-line therapy. Furthermore, 267 of these 879 patients who were resistant to first- or second-generation EGFR-TKIs had received a re-biopsy (including bronchoscopy, chest computed tomography guided biopsy, or video-assisted thoracoscopic surgery) and/or liquid biopsy (the Department of Pathology of Kaohsiung Chang Gung Memorial Hospital was in charged for the detection of the EGFR T790M mutation in cell-free plasma DNA) between March 2015 and December 2018. Of those patients, there were 98 patients with EGFR T790M mutation-positive adenocarcinomas who had received osimertinib therapy ( $80 \mathrm{mg}$ per day) for at least 2 weeks since March 2016. Among these 98 patients, 91 patients were provided with treatment through the expanded access programs supported by AstraZeneca until the occurrence of disease progression or the unacceptable adverse effects. All of the 98 patients who received osimertinib treatment were enrolled for analysis.

Each of these 98 patients regularly received a chest CT scan in initially start of the osimertinib treatment and every three months thereafter to evaluate their tumor responses. Brain MRI imaging and Tc-99m MDP bone scans would also be performed if there were related symptoms. Progression-free survival (PFS), overall survival (OS), overall response rate (ORR), and disease control rate (DCR) were calculated to evaluate their efficacy. The PFS was calculated from the time of starting osimertinib until the time of radiological progression based on RECIST (according to the Response Evaluation Criteria in Solid Tumors) v1.121 or death; with censoring at the time of the last follow-up in the event which the patient was not disease progression. The ORR was defined as the percentage of patients who presented a complete response or partial response in the first follow-up image study after the starting osimertinib treatment, while the DCR was calculated as the percentage of patients who exhibited a complete 
response, partial response, or stable disease. Furthermore, the duration of overall survival was calculated the duration from the starting osimertinib treatment until the patient expired.

\section{Statistical analysis}

Data (including age, sex, tumor size, nodal stage, EGFR mutation subtypes) were collected and analyzed by SPSS for Windows version 15.0. Quantitative variables are presented as averages \pm standard deviations. Statistical significance of univariate analysis was determined by the Mann-Whitney $U$ test for continuous variables and chi-square test for dichotomous variables.

The Kaplan-Meier method was used to estimate the PFS and OS. A Cox proportional hazards regression was also performed to evaluate the determinants of PFS and OS. Differences were considered significant when the $P$-value was $<0.05$.

\section{Results}

The demographic and clinical characteristics of the 98 patients with EGFR T790M mutation-positive adenocarcinomas who received osimertinib therapy are described in Table 1. All the patients had adenocarcinoma histology and were at the advanced stage. The mean age of the patients was $61.12 \pm$ 10.97 (range 34-82) years, and there were 40 (40.8\%) male patients and $58(59.2 \%)$ female patients. The EGFR genotyping at the initial diagnosis showed Del 19 mutations in 54 (55.1\%), L858R mutations in 41 (41.8\%), Del 19 and T790M in one (1.0\%), and L858R and T790M in two (2.0\%) of these adenocarcinoma patients. All the patients were pretreated with EGFR-TKIs: 49 (50.0\%), 27 (27.6\%), and $22(22.4 \%)$ received gefitinib, erlotinib, and afatinib respectively. The EGFR genotyping at the secondary (re-biopsy or liquid biopsy) diagnosis showed Del 19 combined with T790M in 55 (56.1\%) patients and L858R combined with T790M in 43 (43.9\%). The time interval between biopsies was 25.95 \pm 16.56 (1.33-99.10) months.

Forty-five (45.9\%) patients received at least one cycle of chemotherapy between the previous EGFR-TKI and osimertinib. Osimertinib was received by 42 (42.9\%), 23 (23.5\%), and $33(33.7 \%)$ patients as the second-line, third-line, and $\geqq$ fourth-line treatment, respectively. Of the 98 patients, 52 (53.1\%) had partial responses, 31 (31.6\%) had stable diseases, and 15 (15.3\%) experienced disease progression. The overall response rate was $53.1 \%$, and the disease control rate was $84.7 \%$. Among all 98 patients, the median PFS of osimertinib therapy was 10.48 months, and the median OS of osimertinib therapy was 42.21 months.

Table 2 shows the responses to osimertinib treatment after previous therapy with a different first-line EGFR-TKI. There was no significant difference in response rate to osimertinib after previous therapy between the patients treated with the different first-line EGFR-TKIs. The median PFS of those who received osimertinib therapy after previous therapy with gefitinib, afatinib, or erlotinib was $12.83,11.87$, and 10.90 months, respectively $(P=0.293)$ (Supplementary Figure 1$)$. The median OS of those who received osimertinib therapy after previous therapy with gefitinib, afatinib, or erlotinib was $87.93,49.00$, and 42.00 months, respectively (Supplementary Figure 1); there was a significant difference in OS between the patients treated with the different first-line EGFR-TKIs $(P=0.006)$. 
Table 3 shows the response, PFS, and OS results of the patients who received osimertinib treatment after previous chemotherapy (Group A) or immediately following treatment with another EGFR-TKI (Group B). There was no significant difference in overall response rate between these two groups $(62.2 \%$ vs. $45.3 \%$, $\mathrm{P}=0.068)$, but there was a significant difference in disease control rate between these two groups $(93.3 \%$ vs. $77.4 \%, P=0.029)$. There was no significant difference in PFS (12.17 vs. 10.83 months, $P=0.362$ ) or OS (54.27 vs. NA months, $P=0.274$ ) between these two groups.

Furthermore, we compared the response results for the patients treated with osimertinib as the secondline, third-line, or $\geq$ fourth-line therapy (Table 4). There was partial significant difference in median PFS between the patients treated with osimertinib as the second-line, third-line, or $\geq$ fourth-line therapy (10.83, 17.33, and 9.33 months, respectively, $P=0.077$ ) (Supplementary Figure 2), but there was a significant difference in median PFS between the patients treated with osimertinib as the second-line or third-line therapy ( 10.83 vs. 17.33 months, hazard ratio $=0.51,95 \% \mathrm{Cl}=0.26-0.99), \mathrm{P}=0.044$ ) (Supplementary Figure $3)$. There was no significant difference in OS among these patients.

Table 5 shows the subgroup analysis of PFS and OS. In terms of PFS, there were significant differences in the patients with a low BMI level $(P=0.036$, hazard ratio $=0.56,95 \% \mathrm{Cl}=0.32-0.97)$ (Supplementary Figure 4), without COPD ( $P=0.011$, hazard ratio $=0.44,95 \% \mathrm{Cl}=0.23-0.84)$ (Supplementary Figure 5), and without brain metastasis before osimertinib treatment (Patients were without brain metastasis at the time osimertinib was initiated) $(P=0.029$, hazard ratio $=0.56,95 \% \mathrm{Cl}=0.33-0.95)$ (Supplementary Figure 6$)$. In terms of OS, there was a significant difference only in the patients without COPD $(P=0.031$, hazard ratio $=0.45,95 \% \mathrm{Cl}=0.21-0.95)$. Using a Cox proportional hazards regression, we determined that brain metastasis before osimertinib treatment was a poor prognostic factor for PFS and that gefitinib as a firstline therapy and inclusion in Group A (osimertinib treatment after previous chemotherapy) were better prognostic factors for OS (Table 6). Furthermore, COPD tended to be a poor prognostic factor for PFS and OS (Table 6).

\section{Discussion}

In this study, we evaluated the response to osimertinib among NSCLC patients with T790M EGFRresistant mutations following treatment with first- or second-generation EGFR-TKIs. We found that the gefitinib group had better OS (Table 2), that osimertinib treatment after previous chemotherapy (Group A) had a better response rate (Table 3), that osimertinib as the third-line treatment had better PFS than osmertinib as the second-line treatment (Table 4), that brain metastasis noted during osimertinib treatment was a poor prognostic factor for PFS, that gefitinib as a first-line therapy and inclusion in Group A (osimertinib treatment after previous chemotherapy) were better prognostic factors for OS, and that COPD tended to be a poor prognostic factor for PFS and OS (Table 6).

As shown in Table 7. In group A, 12 (26.67\%) patients were with brain metastasis before osimertinib; the PFS was 11.07 months in patients with brain metastasis before osimertinib versus 21.13 months in patients without brain metastasis before osimertinib, respectively. In group B, 20 (37.7\%) patients were 
with brain metastasis before osimertinib; the PFS was 10.27 months in patients with brain metastasis before osimertinib versus 11.87 months in patients without brain metastasis before osimertinib, respectively. So, this could explain osimertinib as the third-line treatment had better PFS than osimertinib as the second-line treatment.

In the LUX-Lung 3 and LUX-Lung 6 trials, OS was significantly longer for patients with EGFR Del19positive tumors in the afatinib group than in the chemotherapy group in both trials: in LUX-Lung 3 , median OS was 33.3 months $(95 \% \mathrm{Cl}=26.8-41.5)$ in the afatinib group versus 21.1 months (16.3-30.7) in the chemotherapy group ( $\mathrm{HR}=0.54,95 \% \mathrm{Cl}=0.36-0.79, \mathrm{p}=0.0015)$; in LUX-Lung 6 , it was 31.4 months $(95 \% \mathrm{Cl}=24.2-35.3)$ versus 18.4 months $(14.6-25.6)$, respectively $(\mathrm{HR}=0.64,95 \% \mathrm{Cl}=0.44-0.94$, $\mathrm{p}=0.023)$. By contrast, there were no significant differences by treatment group for patients with EGFR L858R-positive tumors in either trial. in LUX-Lung 3, median OS was 27.6 months (19.8-41.7) in the afatinib group versus 40.3 months (24.3-not estimable) in the chemotherapy group ( $\mathrm{HR}=1.30,95 \% \mathrm{Cl}=$ 0.80-2.11, $\mathrm{p}=0.29)$; in LUX-Lung 6, it was 19.6 months $(95 \% \mathrm{Cl}=17.0-22.1)$ versus 24.3 months (19.027.0 ), respectively ( $H R 1.22,95 \% \mathrm{Cl} 0.81-1.83, p=0.34$ ). The absence of an effect in patients with $L 858 R$ mutations suggests that EGFR Del19-positive disease might be distinct from EGFR L858R-positive disease[6, 20, 21]. This different EGFR-TKIs effect between Del19 and L858R could also explain why osimertinib as the third-line treatment had better PFS than osimertinib as the second-line treatment in our study. Furthermore, LUX-Lung 3 results suggested cisplatin plus pemetrexed promoted longer PFS in L858R patients (8.1 months) than in Del19 patients (5.6 months); another Japan study results also suggested cisplatin plus pemetrexed regimen may confer higher efficacy for L858R patients in second line or later settings[22]. These suggested that chemotherapy has better survival benefit in L858R-positive than Del19-positive. Table 8 showed the survival difference between L858R and Del19 in our study. In L858R-positive patients, group A and group $B$ have a trend of significant difference in PFS (12.5 months versus 9.0 months, $p=0.319$ ); by contrast, in Del19-positive patients, group $A$ and group $B$ have no significant difference in PFS (15.70 months versus 11.93 months, $p=0.950)$. The survival difference between L858R and Del19 could explain osimertinib as the third-line treatment (chemotherapy treated before osimertinib) had better PFS than osimertinib as the second-line treatment.

Following pretreatment with gefitinib, osimertinib tended to have a better PFS in this study (Table 2). This data was similar to that of another study from Taiwan[23] in which the PFS for patients treated with firstgeneration and second-generation EGFR-TKIs was 20.3 and 11.6 months, respectively (hazard ratio $\mathrm{HR}=0.40,95 \% \mathrm{Cl}=0.18-0.82, \mathrm{P}=0.031$ )[23]. Kuo et al.[23] digital PCR was used in the re-biopsy of the tissues to determine the differences between the alleles frequencies of mEGFR (19del or L858R) $\left(\mathrm{AF}_{\mathrm{mEGFR}}\right)$ and T790M $\left(\mathrm{AF}_{\mathrm{T} 790 \mathrm{M}}\right)$ after acquiring resistance between the first and second generation EGFR-treated. In Kuo's study, the $\mathrm{AF}_{\mathrm{T} 790 \mathrm{M}} / \mathrm{AF}_{\mathrm{mEGFR}}$ ratio of the first-generation EGFR-TKIs treatment group was significantly higher than that of the second-generation EGFR-TKIs treatment group. In addition, there was a highly significant correlation between $A_{T 790 M}$ and $A F_{\text {mEGFR. }}$. This could explain why osimertinib tended to have a better PFS following pretreatment with gefitinib than with afatinib in this study. In our 
study, these data regarding $A F_{T 790 M} / A_{\text {mEGFR }}$ ratio was not available due to its retrospective study. So Kuo's data cannot explain a better PFS following pretreatment with gefitinib than with erlotinib.

In Taiwan, gefitinib (since November 2007) was covered by national reimbursement earlier than erlotinib (since June 2008) and afatinib (since May 2014). Furthermore, osimertinib was approved with secondline use since 2016 and first-line use since 2019, but covered by national reimbursement since April 2020 in Taiwan. The timing difference of approval and national reimbursement time difference could affect outcome between these three first-line EGFR-TKIs.

Compared with the first-generation EGFR-TKIs, the second-generation EGFR-TKI exhibits a broader inhibition spectrum and has an irreversible effect on the tyrosine kinases of EGFR and other ErbB family members.[24] Previous investigations[25-27] have shown that tumors are resistant to second-generation EGFR-TKIs usually show undetectable levels of EGFR and HER2 amplification, which may indicate a greater advantage of activating EGFR mutant clones in tumors. In contrast, in tumors that acquired resistance to the first-generation EGFR-TKI, EGFR and HER2 amplification were found at a consistent frequency, $[13,28]$ suggesting a less dominant place of EGFR-activating mutations in this scenario.

Previous studies Oxnard and Remon yielded controversial results that investigated the predictive role of the T790M allele in liquid biopsies examined the ratio of T790M to activating EGFR-mutation alleles.[29, 30] Oxnard et al.[29] showed that he ratio of T790M to activating EGFR mutations is related to the depth of response to osimertinib treatment, while this association was not noted by Remon et al.[30] in a similar study setting. Instead of liquid biopsy samples, our study showed that using tissue re-biopsies (liquid biopsy: tissue re-biopsy $=31.6 \%: 68.4 \%$, Table 1 ) is feasible for determining the predictive role of the T790M allele.

In our study, there was a trend toward a significant difference in median PFS between the use of osimertinib as a second-line, third-line, or $\geqq$ fourth-line therapy, and there was a significant difference in median PFS between the use of osimertinib as a second-line therapy or third-line therapy (Table 4). This PFS data was different from the data of another study from Taiwan[23] in which the hazard ratio was $1.03(95 \% \mathrm{Cl}=0.44-2.20, \mathrm{P}=0.941)$. Also, the PFS data in our study is different from the PFS data from the AURA II study[31]; in that study, the PFS for osimertinib as the second-line or third-line therapy was 11.0 (6.7-NR) and 12.4 (9.5-15.5) months, respectively. Furthermore, there was no significant difference in OS in both of these studies. Many related studies also describe the effects of using the second EGFR-TKI after the initial exposure [32-36]; furthermore, these previous studies described different results. During chemotherapy, the original EGFR-dependent cells may re-grow, and a second remission may be obtained by introducing EGFR-TKIs after chemotherapy. In addition to sensitivity to acquired T790M mutations, osimertinib is also sensitive to original EGFR mutations (Del 19 and L8585R)[16]. This hypothesis may explain the higher RR and DCR seen in this study (Table 3) as compared with other study results for second-round EGFR-TKIs of different designs[32-35]. 
To detect T790M resistance mutations, in most studies, re-biopsy was performed when the disease progressed[13, 37], and the results showed that T790M accounted for $50-60 \%$ of the resistance mechanism. Since the cancer genome is heterogeneous, it can evolve over time, and it can also interact with different treatments[38], It is unclear whether the timing of a re-biopsy or liquid biopsy will affect the detection rate of T790M. However, in one previous study[39], The results provide evidence that there is no significant association between the timing of re-biopsy and the detection rate of T790M. In addition, this study also shows that T790M can exist for a long time after the progression of EGFR-TKI treatment, and it is also an important carcinogenic driving factor. In our study, the time interval between biopsies was $25.95 \pm 16.56$ (1.33-99.10) months (Table 1); furthermore, the patients treated with gefitinib had a longer time interval between biopsies than those for the patients treated with erlotinib and afatinib. As previous description, gefitinib (since November 2007) was covered by national reimbursement earlier than erlotinib (since June 2008) and afatinib (since May 2014) in Taiwan. So, this could explain why the gefitinib group had a longer PFS than the erlotinib and afatinib groups. Furthermore, osimertinib was approved with second-line use since 2016 and first-line use since 2019, but covered by national reimbursement since April 2020. The timing difference of approval and national reimbursement time difference could affect outcome between these three first-line EGFR-TKIs.

Non-small cell lung cancer is the main cause of brain metastases.[40, 41] Amongst these with recurrent/advanced NSCLC, brain metastases are a common cause for cancer-related morbidity and mortality. As targeted therapy continues to improve the prognosis of NSCLC patients with target oncogene,[8] The deterrence of brain metastases has become an increasingly relevant treatment problem. The first and second generation EGFR-TKIs (ie gefitinib, erlotinib, and afatinib) cannot effectively cross the intact complete blood-brain barrier which the ratio of the patient's cerebrospinal fluid to plasma is as low as 0.01 to 0.003 . In the AURA 3 and FLAURA studies[19, 42], the PFS benefit of osimertinib was observed in patients with or without known or treated brain metastases at trial entry. Patients with brain metastases tended to have a worse PFS benefit (PFS $=15.2,95 \% \mathrm{Cl}=12.1-21.4$ months) than those without brain metastases (PFS $=19.1,95 \% \mathrm{Cl}=15.2-23.5$ months) in EGFR mutation NSCLC patients in the FLAURA study[42]. It seems that this could explain why initial brain metastasis did not influence the osimertinib PFS but brain metastasis during osimertinib treatment did influence the osimertinib PFS in our study.

This retrospective study has several limitations. First, this study was conducted at a single medical center, such that the patient population may be biased by patient selection and referral patterns. Second, this study was a retrospective survey, which not only resulted in incomplete data for some patients, but also did not control for laboratory examinations. Third, the multiple lines of treatment before administering osimertinib may have confounded the effects. Another limitation was that any genomic alterations beyond EGFR mutations were not measured in this study. Only first-generation EGFR-TKIs were enrolled for analysis in AURA 3 trial. Although both first- and second-generation EGFR-TKIs were enrolled for analysis, but it still is a retrospective analysis. In the future, further randomized controlled trial should be conducted to evaluate PFS and OS benefit between different sequences of EKFR-TKIs. 


\section{Conclusion}

We found that the gefitinib group had better OS, that osimertinib treatment after previous chemotherapy (Group A) had a better response rate, that osimertinib as the third-line treatment had a better PFS than osimertinib as the second-line treatment, that brain metastasis noted before osimertinib treatment was a poor prognostic factor for PFS, that gefitinib as a first-line treatment and inclusion in Group A (osimertinib treatment after previous chemotherapy) were better prognostic factors for OS, and that COPD tended to be a poor prognostic factor for PFS and OS. But, osimertinib is still neither easily available nor covered by national reimbursement in many countries. In our study, an alternative sequence (using chemotherapy first when initially osimertinib not available) still s better PFS benefit. Furthermore,

\section{Abbreviations}

COPD: chronic obstructive pulmonary disease

DCR: disease control rate

EGFR: epidermal growth factor receptor

NSCLC: non-small cell lung cancer

ORR: overall response rate

OS: overall survival

PD: disease progression

PFS: progression-free survival

RECIST: Response Evaluation Criteria in Solid Tumors

TKls: tyrosine kinase inhibitors

\section{Declarations}

\section{Ethics approval and consent to participate}

The study was approved by the Institutional Review Board of Chang Gung Memorial Hospital, and the requirements for patient consent were waived (IRB: 201901263B0).

\section{Acknowledgments}

We thank Prof. Sheng-Nan Lu, Prof. Hsueh-Wen Chang, Shin-Yi Chien, Chih-Yun Lin, and the Biostatistics Center, Kaohsiung Chang Gung Memorial Hospital, for the statistics work. We also thank the Chang Gung 
Medical Foundation Kaohsiung Chang Gung Memorial Hospital Tissue Bank Core Facility (CLRPG8B0031 and CLRPG8E0161) for excellent technical support.

\section{Funding}

This study was supported by grants from the Chang Gung Memorial Hospital (CMRPG8E1661 1663, CMRPG8F1351, CMRPG8F1491 1493, and CMPRG8H1201 to Chin-Chou Wang. CMRPG8F1441 to ChiaCheng Tseng). The funding body had no role in the design of the study and collection, analysis, and interpretation of data and in writing the manuscript.

\section{Competing interests statement}

The authors state that that there no potential conflicts of interest.

\section{Author contributors}

Conception and design: CCW and CHL. Acquisition of data: CCW, CHL, CCT, HCC, KTH, and MCL. Data analysis and interpretation: CCW, CHL, and CCT. Manuscript writing: all authors. Final approval of manuscript: all authors.

\section{Availability of data and materials}

The datasets analyzed during the current study would be available from the corresponding author on reasonable request.

\section{References}

1. Bulbul A, Husain H: First-Line Treatment in EGFR Mutant Non-Small Cell Lung Cancer: Is There a Best Option?Frontiers in oncology 2018, 8:94.

2. Kohno T, Nakaoku T, Tsuta K, Tsuchihara K, Matsumoto S, Yoh K, Goto K: Beyond ALK-RET, ROS1 and other oncogene fusions in lung cancer. Translational lung cancer research 2015, 4(2):156-164.

3. Shi Y, Au JS, Thongprasert S, Srinivasan S, Tsai CM, Khoa MT, Heeroma K, Itoh Y, Cornelio G, Yang PC: A prospective, molecular epidemiology study of EGFR mutations in Asian patients with advanced non-small-cell lung cancer of adenocarcinoma histology (PIONEER). J Thorac Oncol 2014, 9(2):154162.

4. Herbst RS, Morgensztern D, Boshoff C: The biology and management of non-small cell lung cancer. Nature 2018, 553(7689):446-454.

5. Thomas A, Liu SV, Subramaniam DS, Giaccone G: Refining the treatment of NSCLC according to histological and molecular subtypes. Nature Reviews Clinical Oncology 2015, 12:511.

6. Sequist LV, Yang JC, Yamamoto N, O'Byrne K, Hirsh V, Mok T, Geater SL, Orlov S, Tsai CM, Boyer M et al: Phase III study of afatinib or cisplatin plus pemetrexed in patients with metastatic lung 
adenocarcinoma with EGFR mutations. Journal of clinical oncology : official journal of the American Society of Clinical Oncology 2013, 31(27):3327-3334.

7. Mitsudomi T, Morita S, Yatabe Y, Negoro S, Okamoto I, Tsurutani J, Seto T, Satouchi M, Tada H, Hirashima T et al: Gefitinib versus cisplatin plus docetaxel in patients with non-small-cell lung cancer harbouring mutations of the epidermal growth factor receptor (WJTOG3405): an open label, randomised phase 3 trial. Lancet Oncol 2010, 11(2):121-128.

8. Rosell R, Carcereny E, Gervais R, Vergnenegre A, Massuti B, Felip E, Palmero R, Garcia-Gomez R, Pallares C, Sanchez JM et al: Erlotinib versus standard chemotherapy as first-line treatment for European patients with advanced EGFR mutation-positive non-small-cell lung cancer (EURTAC): a multicentre, open-label, randomised phase 3 trial. Lancet Oncol 2012, 13(3):239-246.

9. Zhou C, Wu YL, Chen G, Feng J, Liu XQ, Wang C, Zhang S, Wang J, Zhou S, Ren S et al: Erlotinib versus chemotherapy as first-line treatment for patients with advanced EGFR mutation-positive nonsmall-cell lung cancer (OPTIMAL, CTONG-0802): a multicentre, open-label, randomised, phase 3 study. Lancet Oncol2011, 12(8):735-742.

10. Lynch TJ, Bell DW, Sordella R, Gurubhagavatula S, Okimoto RA, Brannigan BW, Harris PL, Haserlat SM, Supko JG, Haluska FG et al: Activating mutations in the epidermal growth factor receptor underlying responsiveness of non-small-cell lung cancer to gefitinib. The New England journal of medicine 2004, 350(21):2129-2139.

11. Maemondo M, Inoue A, Kobayashi K, Sugawara S, Oizumi S, Isobe H, Gemma A, Harada M, Yoshizawa $\mathrm{H}$, Kinoshita I et al: Gefitinib or chemotherapy for non-small-cell lung cancer with mutated EGFR. The New England journal of medicine 2010, 362(25):2380-2388.

12. Paez JG, Janne PA, Lee JC, Tracy S, Greulich H, Gabriel S, Herman P, Kaye FJ, Lindeman N, Boggon $\mathrm{TJ}$ et al: EGFR mutations in lung cancer: correlation with clinical response to gefitinib therapy. Science 2004, 304(5676):1497-1500.

13. Yu HA, Arcila ME, Rekhtman N, Sima CS, Zakowski MF, Pao W, Kris MG, Miller VA, Ladanyi M, Riely $\mathrm{GJ}$ : Analysis of tumor specimens at the time of acquired resistance to EGFR-TKI therapy in $\mathbf{1 5 5}$ patients with EGFR-mutant lung cancers. Clin Cancer Res 2013, 19(8):2240-2247.

14. Ohashi K, Maruvka YE, Michor F, Pao W: Epidermal growth factor receptor tyrosine kinase inhibitorresistant disease. Journal of clinical oncology : official journal of the American Society of Clinical Oncology 2013, 31(8):1070-1080.

15. Kobayashi S, Boggon TJ, Dayaram T, Janne PA, Kocher O, Meyerson M, Johnson BE, Eck MJ, Tenen DG, Halmos B: EGFR mutation and resistance of non-small-cell lung cancer to gefitinib. The New England journal of medicine 2005, 352(8):786-792.

16. Cross DA, Ashton SE, Ghiorghiu S, Eberlein C, Nebhan CA, Spitzler PJ, Orme JP, Finlay MR, Ward RA, Mellor MJ et al: AZD9291, an irreversible EGFR TKI, overcomes T790M-mediated resistance to EGFR inhibitors in lung cancer. Cancer discovery 2014, 4(9):1046-1061.

17. Goss G, Tsai CM, Shepherd FA, Bazhenova L, Lee JS, Chang GC, Crino L, Satouchi M, Chu Q, Hida T et al: Osimertinib for pretreated EGFR Thr790Met-positive advanced non-small-cell lung cancer 
(AURA2): a multicentre, open-label, single-arm, phase 2 study. Lancet Onco/ 2016, 17(12):1643-1652.

18. Janne PA, Yang JC, Kim DW, Planchard D, Ohe Y, Ramalingam SS, Ahn MJ, Kim SW, Su WC, Horn L et al: AZD9291 in EGFR inhibitor-resistant non-small-cell lung cancer. The New England journal of medicine 2015, 372(18):1689-1699.

19. Mok TS, Wu YL, Ahn MJ, Garassino MC, Kim HR, Ramalingam SS, Shepherd FA, He Y, Akamatsu H, Theelen WS et al: Osimertinib or Platinum-Pemetrexed in EGFR T790M-Positive Lung Cancer. The New England journal of medicine 2017, 376(7):629-640.

20. Yang JC, Wu YL, Schuler M, Sebastian M, Popat S, Yamamoto N, Zhou C, Hu CP, O'Byrne K, Feng J et al: Afatinib versus cisplatin-based chemotherapy for EGFR mutation-positive lung adenocarcinoma (LUX-Lung 3 and LUX-Lung 6): analysis of overall survival data from two randomised, phase 3 trials. Lancet Oncol 2015, 16(2):141-151.

21. Wu YL, Zhou C, Hu CP, Feng J, Lu S, Huang Y, Li W, Hou M, Shi JH, Lee KY et al: Afatinib versus cisplatin plus gemcitabine for first-line treatment of Asian patients with advanced non-small-cell lung cancer harbouring EGFR mutations (LUX-Lung 6): an open-label, randomised phase 3 trial. Lancet Oncol 2014, 15(2):213-222.

22. Kaneda T, Yoshioka H, Tamiya M, Tamiya A, Hata A, Okada A, Niwa T, Shiroyama T, Kanazu M, Ishida $T$ et al: Differential efficacy of cisplatin plus pemetrexed between L858R and Del-19 in advanced EGFR-mutant non-squamous non-small cell lung cancer. BMC cancer 2018, 18(1):6.

23. Kuo CS, Huang CH, Liu CY, Pavlidis S, Ko HW, Chung FT, Lin TY, Wang CL, Guo YK, Yang CT: Prior EGFR-TKI Treatment in EGFR-Mutated NSCLC Affects the Allele Frequency Fraction of Acquired T790M and the Subsequent Efficacy of Osimertinib. Targeted oncology 2019, 14(4):433-440.

24. Liao BC, Lin CC, Yang JC: Second and third-generation epidermal growth factor receptor tyrosine kinase inhibitors in advanced nonsmall cell lung cancer. Current opinion in oncology 2015, 27(2):94101.

25. Iwama E, Sakai K, Azuma K, Harada D, Nosaki K, Hotta K, Nishio M, Kurata T, Fukuhara T, Akamatsu $\mathrm{H}$ et al: Exploration of resistance mechanisms for epidermal growth factor receptor-tyrosine kinase inhibitors based on plasma analysis by digital polymerase chain reaction and next-generation sequencing. Cancer science 2018, 109(12):3921-3933.

26. Campo M, Gerber D, Gainor JF, Heist RS, Temel JS, Shaw AT, Fidias P, Muzikansky A, Engelman JA, Sequist LV: Acquired Resistance to First-Line Afatinib and the Challenges of Prearranged Progression Biopsies. J Thorac Oncol 2016, 11(11):2022-2026.

27. Wu SG, Liu YN, Tsai MF, Chang YL, Yu CJ, Yang PC, Yang JC, Wen YF, Shih JY: The mechanism of acquired resistance to irreversible EGFR tyrosine kinase inhibitor-afatinib in lung adenocarcinoma patients. Oncotarget 2016, 7(11):12404-12413.

28. Sequist LV, Waltman BA, Dias-Santagata D, Digumarthy S, Turke AB, Fidias P, Bergethon K, Shaw AT, Gettinger S, Cosper AK et al: Genotypic and histological evolution of lung cancers acquiring resistance to EGFR inhibitors. Science translational medicine 2011, 3(75):75ra26. 
29. Oxnard GR, Thress KS, Alden RS, Lawrance R, Paweletz CP, Cantarini M, Yang JC, Barrett JC, Janne PA: Association Between Plasma Genotyping and Outcomes of Treatment With Osimertinib (AZD9291) in Advanced Non-Small-Cell Lung Cancer. Journal of clinical oncology : official journal of the American Society of Clinical Oncology 2016, 34(28):3375-3382.

30. Remon J, Caramella C, Jovelet C, Lacroix L, Lawson A, Smalley S, Howarth K, Gale D, Green E, Plagnol $V$ et al: Osimertinib benefit in EGFR-mutant NSCLC patients with T790M-mutation detected by circulating tumour DNA. Annals of oncology : official journal of the European Society for Medical Oncology / ESMO 2017, 28(4):784-790.

31. Yang JC, Ahn MJ, Kim DW, Ramalingam SS, Sequist LV, Su WC, Kim SW, Kim JH, Planchard D, Felip E et al: Osimertinib in Pretreated T790M-Positive Advanced Non-Small-Cell Lung Cancer: AURA Study Phase II Extension Component. Journal of clinical oncology : official journal of the American Society of Clinical Oncology 2017, 35(12):1288-1296.

32. Viswanathan A, Pillot G, Govindan R: Lack of response to erlotinib after progression on gefitinib in patients with advanced non-small cell lung cancer. Lung Cancer 2005, 50(3):417-418.

33. Cho BC, Im CK, Park MS, Kim SK, Chang J, Park JP, Choi HJ, Kim YJ, Shin SJ, Sohn JH et al: Phase II study of erlotinib in advanced non-small-cell lung cancer after failure of gefitinib. Journal of clinical oncology : official journal of the American Society of Clinical Oncology 2007, 25(18):2528-2533.

34. Lee DH, Kim SW, Suh C, Yoon DH, Yi EJ, Lee JS: Phase II study of erlotinib as a salvage treatment for non-small-cell lung cancer patients after failure of gefitinib treatment. Annals of oncology : official journal of the European Society for Medical Oncology / ESMO 2008, 19(12):2039-2042.

35. Wong AS, Soong R, Seah SB, Lim SW, Chuah KL, Nga ME, Chin TM, Soo RA: Evidence for disease control with erlotinib after gefitinib failure in typical gefitinib-sensitive Asian patients with non-small cell lung cancer. J Thorac Oncol 2008, 3(4):400-404.

36. Oh IJ, Ban HJ, Kim KS, Kim YC: Retreatment of gefitinib in patients with non-small-cell lung cancer who previously controlled to gefitinib: a single-arm, open-label, phase Il study. Lung Cancer 2012, 77(1):121-127.

37. Arcila ME, Oxnard GR, Nafa K, Riely GJ, Solomon SB, Zakowski MF, Kris MG, Pao W, Miller VA, Ladanyi M: Rebiopsy of lung cancer patients with acquired resistance to EGFR inhibitors and enhanced detection of the T790M mutation using a locked nucleic acid-based assay. Clin Cancer Res 2011, 17(5):1169-1180.

38. Sabaawy HE: Genetic Heterogeneity and Clonal Evolution of Tumor Cells and their Impact on Precision Cancer Medicine. Journal of leukemia (Los Angeles, Calif) 2013, 1(4):1000124.

39. Tseng JS, Su KY, Yang TY, Chen KC, Hsu KH, Chen HY, Tsai CR, Yu SL, Chang GC: The emergence of T790M mutation in EGFR-mutant lung adenocarcinoma patients having a history of acquired resistance to EGFR-TKI: focus on rebiopsy timing and long-term existence of T790M. Oncotarget 2016, 7(30):48059-48069.

40. Nayak L, Lee EQ, Wen PY: Epidemiology of brain metastases. Current oncology reports 2012, 14(1):48-54. 
41. Rangachari D, Yamaguchi N, VanderLaan PA, Folch E, Mahadevan A, Floyd SR, Uhlmann EJ, Wong ET, Dahlberg SE, Huberman MS et al: Brain metastases in patients with EGFR-mutated or ALKrearranged non-small-cell lung cancers. Lung Cancer 2015, 88(1):108-111.

42. Soria JC, Ohe Y, Vansteenkiste J, Reungwetwattana T, Chewaskulyong B, Lee KH, Dechaphunkul A, Imamura F, Nogami N, Kurata T et al: Osimertinib in Untreated EGFR-Mutated Advanced Non-SmallCell Lung Cancer. The New England journal of medicine 2018, 378(2):113-125.

\section{Tables}

Table 1. Demographic and clinical characteristics of all patients. $(n=98)$ 


\begin{tabular}{|c|c|c|c|}
\hline \multirow[t]{2}{*}{ Sex } & Male & \multicolumn{2}{|c|}{$40(40.8 \%)$} \\
\hline & Female & \multicolumn{2}{|c|}{$58(59.2 \%)$} \\
\hline Age (in years) & & \multicolumn{2}{|c|}{$61.12 \pm 10.97$ (34-82) } \\
\hline$>65$ & & \multicolumn{2}{|c|}{35 (35.7\%) } \\
\hline$\leq 65$ & & \multicolumn{2}{|c|}{$63(64.3 \%)$} \\
\hline BMI & & \multicolumn{2}{|c|}{$24.45 \pm 3.49(16.24-33.06)$} \\
\hline Tumor size (in cm) & & \multicolumn{2}{|c|}{$4.30 \pm 2.17(0.8-15.0)$} \\
\hline \multicolumn{4}{|l|}{$N=63$} \\
\hline \multirow[t]{3}{*}{ Stage } & IIIA & & $1(1.1 \%)$ \\
\hline & IIIB & & $2(3.2 \%)$ \\
\hline & IV & & $95(95.9 \%)$ \\
\hline \multirow[t]{4}{*}{ First EGFR mutation test } & Del 19 & & $54(55.1 \%)$ \\
\hline & L858R & & $41(41.8 \%)$ \\
\hline & Del $19 \varepsilon$ & $790 M$ & $1(1.0 \%)$ \\
\hline & L858R & $790 M$ & $2(2.0 \%)$ \\
\hline \multirow[t]{2}{*}{ Second EGFR mutation test } & Del $19 \varepsilon$ & $790 M$ & $55(56.1 \%)$ \\
\hline & L858R & $790 M$ & $43(43.9 \%)$ \\
\hline \multirow[t]{4}{*}{ ECOG } & 0 & & $29(29.6 \%)$ \\
\hline & 1 & & $67(68.4 \%)$ \\
\hline & 2 & & $2(2.0 \%)$ \\
\hline & $3-4$ & & $0(0 \%)$ \\
\hline \multirow[t]{3}{*}{ Comorbidities } & DM & & $9(9.2 \%)$ \\
\hline & COPD & & $12(12.2 \%)$ \\
\hline & Hyperte & & $23(23.5 \%)$ \\
\hline \multirow[t]{3}{*}{ Smoking status } & Never & & 77 (78.6\%) \\
\hline & Ever & & $12(12.2 \%)$ \\
\hline & Current & & $9(9.2 \%)$ \\
\hline \multirow[t]{2}{*}{ CEA level } & $\leq 5$ & & $33(33.7 \%)$ \\
\hline & $>5$ & & 65 (66.3\%) \\
\hline
\end{tabular}




\begin{tabular}{|c|c|c|}
\hline \multirow{5}{*}{$\begin{array}{l}\text { Diagnosis at } \\
\text { first presentation }\end{array}$} & Bronchoscopy & $41(41.8 \%)$ \\
\hline & CT-guide & $21(21.4 \%)$ \\
\hline & Operation & $20(20.4 \%)$ \\
\hline & Pleural effusion & $15(15.3 \%)$ \\
\hline & LN aspiration & $1(1.0 \%)$ \\
\hline \multirow{5}{*}{$\begin{array}{l}\text { Diagnosis at } \\
\text { second presentation }\end{array}$} & Bronchoscopy & $10(10.2 \%)$ \\
\hline & CT-guide & $18(18.4 \%)$ \\
\hline & Operation & $23(23.5 \%)$ \\
\hline & Pleural effusion & $16(16.3 \%)$ \\
\hline & Plasma DNA & $31(31.6 \%)$ \\
\hline Time interval between biopsies (in months) & \multicolumn{2}{|c|}{$25.95 \pm 16.56(1.33-99.10)$} \\
\hline \multirow[t]{3}{*}{ First-line therapy } & Geftinib & $49(50.0 \%)$ \\
\hline & Erlotinib & $27(27.6 \%)$ \\
\hline & Afatinib & $22(22.4 \%)$ \\
\hline \multirow[t]{3}{*}{ Osimertinib therapy } & Second line & $42(42.9 \%)$ \\
\hline & Third line & $23(23.5 \%)$ \\
\hline & $\geqq$ Fourth line & $33(33.7 \%)$ \\
\hline \multicolumn{2}{|c|}{$\begin{array}{l}\text { Chemotherapy of at least one cycle between previous EGFR-TKI and } \\
\text { osimertinib }\end{array}$} & $45(45.9 \%)$ \\
\hline \multicolumn{2}{|l|}{ Interval between 2 TKIs* } & $2 \pm 7.31(0.87-27.23)$ \\
\hline \multicolumn{2}{|l|}{ 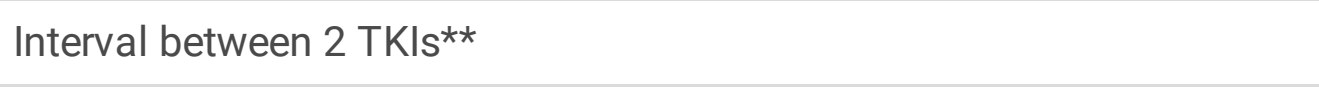 } & $8 \pm 6.83(0-27.23)$ \\
\hline \multirow[t]{4}{*}{ Osimertinib response } & $\mathrm{CR}$ & $0(0 \%)$ \\
\hline & PR & $52(53.1 \%)$ \\
\hline & SD & $31(31.6 \%)$ \\
\hline & PD & $15(15.3 \%)$ \\
\hline Death & $43(43.9 \%)$ & \\
\hline Osimertinib therapy failure & $65(66.3 \%)$ & \\
\hline Osimertinib therapy PFS total (median, in months) & 10.48 & \\
\hline OS (median, in months) & 42.21 & \\
\hline
\end{tabular}


* Excluding the data of osimertinib use immediately after previous EGFR-TKI therapy ( $n=53$, Group B). ** All patients $(n=98)$.

Table 2. Response to osimertinib treatment after previous therapy with a different first-line EGFR-TKI $(n=98)$.

\begin{tabular}{|lllll|}
\hline GROUP & $\begin{array}{l}\text { Geftinib } \\
(\boldsymbol{n = 4 9 , 5 0 . 0 \% )})\end{array}$ & $\begin{array}{l}\text { Afatinib } \\
(\boldsymbol{n}=\mathbf{2 2 , 2 2 . 4 \% )}\end{array}$ & $\begin{array}{l}\text { Erlotinib } \\
(\boldsymbol{n}=\mathbf{2 7}, \mathbf{2 7 . 6 \%})\end{array}$ & P-value \\
\hline PR & $29(59.2 \%)$ & $9(40.9 \%)$ & $14(51.9 \%)$ & 0.673 \\
\hline SD & $14(28.6 \%)$ & $9(40.9 \%)$ & $8(29.6 \%)$ & \\
\hline PD & $6(12.2 \%)$ & $4(18.2 \%)$ & $5(18.5 \%)$ & \\
\hline PFS (in months) & 12.83 & 11.87 & 10.90 & 0.293 \\
\hline OS (in months) & 87.93 & 49.00 & 42.00 & 0.006 \\
\hline Pearson's chi-squared test. & & & \\
PR= partial response, SD= stable disease, PR= progression disease. & \\
\hline
\end{tabular}

Table 3. Response, PFS, and OS of the patients who received osimertinib treatment after previous chemotherapy (Group A) or immediately following treatment with another EGFR-TKI (Group B). ( $n=98$ ) 


\begin{tabular}{|c|c|c|c|}
\hline GROUP & $\begin{array}{l}\text { After Chemotherapy (Group A) } \\
(n=45,45.9 \%)\end{array}$ & $\begin{array}{l}\text { After Another EGFR-TKI (Group B) } \\
(n=53,54.1 \%)\end{array}$ & $P$-value \\
\hline PR & $28(62.2 \%)$ & $24(45.3 \%)$ & 0.068 \\
\hline SD & $14(31.1 \%)$ & $17(32.1 \%)$ & \\
\hline PD & $3(6.7 \%)$ & $12(22.6 \%)$ & \\
\hline DCR & $42(93.3 \%)$ & $41(77.4 \%)$ & 0.029 \\
\hline PD & $3(6.7 \%)$ & $12(22.6 \%)$ & \\
\hline PFS (in months) & 12.17 & 10.83 & $0.362^{*}$ \\
\hline OS (in months) & 54.27 & NA & $0.274 * \star$ \\
\hline \multicolumn{4}{|c|}{ Pearson's chi-squared test. } \\
\hline \multicolumn{4}{|c|}{$\begin{array}{l}\mathrm{PR}=\text { partial response, } \mathrm{SD}=\text { stable disease, } \mathrm{PR}=\text { progression disease, } \mathrm{DCR}=\text { disease control rate. } \mathrm{PFS}= \\
\text { median progression free survival, } \mathrm{OS}=\text { median overall survival. }\end{array}$} \\
\hline \multicolumn{4}{|c|}{ *PFS Hazard Ratio: 0.80 (0.49-1.30). **OS Hazard Ratio: 1.40 (0.76-2.58). } \\
\hline
\end{tabular}

Table 4. OS and PFS of T790M-mutated lung adenocarcinoma patients treated with osimertinib as second-line, third-line or $\geq$ fourth-line therapy. $(n=98)$

\begin{tabular}{|c|c|c|c|c|}
\hline GROUP & $\begin{array}{l}\text { Second-line } \\
(n=42,42.9 \%)\end{array}$ & $\begin{array}{l}\text { Third-line } \\
(n=23,23.5 \%)\end{array}$ & $\begin{array}{l}\geq \text { Fourth-line } \\
(n=33,33.7 \%)\end{array}$ & $P$-value \\
\hline \multicolumn{5}{|c|}{ Between $2^{\text {nd }}, 3^{\text {rd }}, \& \geq 4^{\text {th }}$ line } \\
\hline PFS (in months) & 10.83 & 17.33 & 9.33 & 0.077 \\
\hline OS (in months) & $\mathrm{N} / \mathrm{A}$ & $\mathrm{N} / \mathrm{A}$ & 54.27 & 0.431 \\
\hline \multicolumn{5}{|c|}{ Between $2^{\text {nd }} \& 3^{\text {rd }}$ line } \\
\hline PFS (in months) & 10.83 & 17.33 & & $0.044^{*}$ \\
\hline OS (in months) & $\mathrm{N} / \mathrm{A}$ & $\mathrm{N} / \mathrm{A}$ & & $0.740 * \star$ \\
\hline \multicolumn{5}{|c|}{ PFS= median progression free survival, OS= median overall survival. } \\
\hline
\end{tabular}

Table 5. Median of PFS and OS of T90M-mutated lung adenocarcinoma patients. (Subgroup analysis) $(n=98)$ 


\begin{tabular}{|c|c|c|c|c|}
\hline \multicolumn{3}{|l|}{ GROUP } & \multirow{3}{*}{$\begin{array}{l}P- \\
\text { value }\end{array}$} & \multirow{3}{*}{$\begin{array}{l}\text { Hazard Ratio } \\
(95 \% \mathrm{Cl})\end{array}$} \\
\hline Months after receiving a previous & $<1$ month & $\geq 1$ month & & \\
\hline Eurk-InI & $(n=48,49.0 \%)$ & $(n=50,51.0 \%)$ & & \\
\hline PFS (in months) & 10.30 & 13.17 & 0.109 & $\begin{array}{l}0.67(0.41 \\
-1.10)\end{array}$ \\
\hline OS (in months) & 67.10 & 56.37 & 0.930 & $\begin{array}{l}1.03(0.56 \\
-1.90)\end{array}$ \\
\hline BMI level & $\begin{array}{l}<27(n=76, \\
77.6 \%)\end{array}$ & $\begin{array}{l}\geq 27(n=22, \\
22.4 \%)\end{array}$ & & \\
\hline PFS (in months) & 13.10 & 9.25 & 0.036 & $\begin{array}{l}0.56(0.32 \\
-0.97)\end{array}$ \\
\hline OS (in months) & 61.20 & 42.00 & 0.192 & $\begin{array}{l}0.64(0.33 \\
-1.25)\end{array}$ \\
\hline CEA level & $\begin{array}{l}\leq 5(n=33 \\
33.7 \%)\end{array}$ & $\begin{array}{l}>5(n=65, \\
66.3 \%)\end{array}$ & & \\
\hline PFS (in months) & 12.07 & 12.13 & 0.901 & $\begin{array}{l}0.97(0.57 \\
-1.63)\end{array}$ \\
\hline OS (in months) & 59.27 & 61.00 & 0.987 & $\begin{array}{l}0.99(0.53 \\
-1.87)\end{array}$ \\
\hline DM & $\begin{array}{l}\text { Without }(n=89 \text {, } \\
90.8 \%)\end{array}$ & $\begin{array}{l}\text { With }(n=9 \text {, } \\
9.2 \%)\end{array}$ & & \\
\hline PFS (in months) & 12.43 & 10.90 & 0.739 & $\begin{array}{l}0.87(0.37 \\
-2.01)\end{array}$ \\
\hline OS (in months) & 59.27 & 46.43 & 0.827 & $\begin{array}{l}0.90(0.35 \\
-2.31)\end{array}$ \\
\hline HTN & $\begin{array}{l}\text { Without }(n=75 \text {, } \\
76.5 \%)\end{array}$ & $\begin{array}{l}\text { With }(n=23 \text {, } \\
23.5 \%)\end{array}$ & & \\
\hline PFS (in months) & 12.07 & 10.90 & 0.544 & $\begin{array}{l}1.20(0.66 \\
-2.17)\end{array}$ \\
\hline OS (in months) & 54.27 & 87.93 & 0.334 & $\begin{array}{l}1.44(0.68 \\
-3.03)\end{array}$ \\
\hline COPD & $\begin{array}{l}\text { Without }(n=86 \text {, } \\
87.8 \%)\end{array}$ & $\begin{array}{l}\text { With }(n=12, \\
12.2 \%)\end{array}$ & & \\
\hline PFS (in months) & 12.43 & 5.89 & 0.011 & $\begin{array}{l}0.44(0.23 \\
-0.84)\end{array}$ \\
\hline OS (in months) & 61.20 & 38.52 & 0.031 & $\begin{array}{l}0.45(0.21 \\
-0.95)\end{array}$ \\
\hline
\end{tabular}




\begin{tabular}{|c|c|c|c|c|}
\hline GROUP & & & $\begin{array}{l}P \text { - } \\
\text { value }\end{array}$ & $\begin{array}{l}\text { Hazard Ratio } \\
(95 \% \mathrm{Cl})\end{array}$ \\
\hline Initial Brain Metastasis & $\begin{array}{l}\text { Without (n=84, } \\
85.7 \%)\end{array}$ & $\begin{array}{l}\text { With }(n=14 \text {, } \\
\text { 14.3\%) }\end{array}$ & & \\
\hline PFS (in months) & 12.43 & 11.00 & 0.347 & $\begin{array}{l}0.71(0.35 \\
-1.45)\end{array}$ \\
\hline OS (in months) & 61.00 & 59.27 & 0.235 & $\begin{array}{l}0.63(0.29 \\
-1.36)\end{array}$ \\
\hline Brain Metastasis (osi) & $\begin{array}{l}\text { Without }(n=66 \text {, } \\
67.3 \%)\end{array}$ & $\begin{array}{l}\text { With (n=32, } \\
32.7 \%)\end{array}$ & & \\
\hline PFS (in months) & 13.87 & 10.90 & 0.029 & $\begin{array}{l}0.56(0.33 \\
-0.95)\end{array}$ \\
\hline OS (in months) & 66.53 & 47.90 & 0.088 & $\begin{array}{l}0.59(0.32 \\
-1.09)\end{array}$ \\
\hline
\end{tabular}

Table 6. Cox regression analysis: effects of potential prognostic factors on PFS and OS for T790Mmutated lung adenocarcinoma. 


\begin{tabular}{|c|c|c|c|c|c|}
\hline \multirow[b]{2}{*}{ Prognostic Factor } & \multirow[b]{2}{*}{ Classification } & \multicolumn{2}{|c|}{$\begin{array}{l}\text { Progression-Free } \\
\text { Survival }\end{array}$} & \multicolumn{2}{|c|}{ Overall Survival } \\
\hline & & $\begin{array}{l}\text { Hazard } \\
\text { Ratio }\end{array}$ & $\begin{array}{l}P- \\
\text { Value }\end{array}$ & $\begin{array}{l}\text { Hazard } \\
\text { Ratio }\end{array}$ & $\begin{array}{l}P- \\
\text { Value }\end{array}$ \\
\hline First-Line Drug & $\begin{array}{l}\text { Afatinib vs. } \\
\text { Erlotinib }\end{array}$ & $\begin{array}{l}1.02(0.47 \\
-2.22)\end{array}$ & 0.959 & $\begin{array}{l}0.97(0.37 \\
-2.56)\end{array}$ & 0.953 \\
\hline First-Line Drug & $\begin{array}{l}\text { Geftinib vs. } \\
\text { Erlotinib }\end{array}$ & $\begin{array}{l}0.79(0.42 \\
-1.47)\end{array}$ & 0.452 & $\begin{array}{l}0.30(0.14 \\
-0.66)\end{array}$ & $0.003 *$ \\
\hline Group & A vs. $B$ & $\begin{array}{l}3.24(0.72 \\
-14.7)\end{array}$ & 0.127 & $\begin{array}{l}13.7(1.39 \\
-135)\end{array}$ & $0.025^{\star}$ \\
\hline $\begin{array}{l}\text { Months after receiving a } \\
\text { previous EGFR-TKI }\end{array}$ & $\begin{array}{l}\text { zone month vs. } \\
\text { <one month }\end{array}$ & $\begin{array}{l}0.33(0.08 \\
-1.27)\end{array}$ & 0.107 & $\begin{array}{l}0.12(0.01 \\
-1.10)\end{array}$ & 0.061 \\
\hline Osimertinib Line Drug & $\begin{array}{l}\text { Third line vs. } \\
\text { Second line }\end{array}$ & $\begin{array}{l}0.50(0.20 \\
-1.26)\end{array}$ & 0.145 & $\begin{array}{l}0.67(0.21 \\
-2.16)\end{array}$ & 0.507 \\
\hline Osimertinib Line Drug & $\begin{array}{l}\text { Fourth line vs. } \\
\text { Second line }\end{array}$ & $\begin{array}{l}1.00(0.47 \\
-2.14)\end{array}$ & 0.996 & $\begin{array}{l}1.01(0.39 \\
-2.65)\end{array}$ & 0.977 \\
\hline BMI & $\begin{array}{l}\mathrm{BMl}<27 \text { vs. } \mathrm{BMI} \\
\geq 27\end{array}$ & $\begin{array}{l}0.68(0.36 \\
-1.29)\end{array}$ & 0.237 & $\begin{array}{l}0.73(0.32 \\
-1.65)\end{array}$ & 0.451 \\
\hline CEA level & $\leq 5$ vs. $>5$ & $\begin{array}{l}0.98(0.54 \\
-1.78)\end{array}$ & 0.944 & $\begin{array}{l}1.03(0.50 \\
-2.13)\end{array}$ & 0.939 \\
\hline Smoking & Never vs. Current & $\begin{array}{l}0.97(0.41 \\
-2.26)\end{array}$ & 0.935 & $\begin{array}{l}1.04(0.39 \\
-2.80)\end{array}$ & 0.932 \\
\hline Smoking & $\begin{array}{l}\text { Experienced vs. } \\
\text { Current }\end{array}$ & $\begin{array}{l}0.95(0.32 \\
-2.82)\end{array}$ & 0.922 & $\begin{array}{l}0.56(0.13 \\
-2.35)\end{array}$ & 0.427 \\
\hline Diabetes Mellitus & No vs. Yes & $\begin{array}{l}0.66(0.25 \\
-1.72)\end{array}$ & 0.391 & $\begin{array}{l}0.67(0.20 \\
-2.22)\end{array}$ & 0.512 \\
\hline Hypertension & No vs. Yes & $\begin{array}{l}1.15(0.59 \\
-2.24)\end{array}$ & 0.690 & $\begin{array}{l}1.67(0.69 \\
-4.06)\end{array}$ & 0.255 \\
\hline Initial Brain Metastasis & No vs. Yes & $\begin{array}{l}1.15(0.46 \\
-2.90)\end{array}$ & 0.767 & $\begin{array}{l}0.81(0.28 \\
-2.34)\end{array}$ & 0.703 \\
\hline Brain Metastasis (OSI) & No vs. Yes & $\begin{array}{l}0.50(0.26 \\
-0.99)\end{array}$ & $0.045^{\star}$ & $\begin{array}{l}0.52(0.21 \\
-1.28)\end{array}$ & 0.155 \\
\hline COPD & No vs. Yes & $\begin{array}{l}0.48(0.23 \\
-1.00)\end{array}$ & 0.051 & $\begin{array}{l}0.40(0.16 \\
-1.01)\end{array}$ & 0.052 \\
\hline $\begin{array}{l}\mathrm{PFS}=\text { median progress } \\
\text { after previous chemoth } \\
\text { another EGFR-TKI. Brair }\end{array}$ & $\begin{array}{l}\text { vival, OS = med } \\
\text { p B= osimertin } \\
\text { s }(\text { OSI })=\text { brain }\end{array}$ & $\begin{array}{l}\text { rall surviv } \\
\text { nent imm } \\
\text { asis was }\end{array}$ & $\begin{array}{l}\text { oup A } \\
\text { ely fol } \\
\text { befol }\end{array}$ & $\begin{array}{l}\text { simertinib } \\
\text { ing treatm } \\
\text { simertinib }\end{array}$ & $\begin{array}{l}\text { tment } \\
\text { with } \\
\text { itment. }\end{array}$ \\
\hline
\end{tabular}


Table 7. PFS and OS of the patients who received osimertinib treatment after previous chemotherapy (Group A) or immediately following treatment with another EGFR-TKI (Group B). Brain metastasis before osimertinib subgroup analysis. $(n=98)$

In group $\mathrm{A}$

\begin{tabular}{|llll|}
\hline Brain metastasis (OSI) & NO & YES & P value \\
\hline Total $n=45$ & $33(73.3 \%)$ & $12(26.67 \%)$ & \\
PFS (months) & 21.13 & 11.07 & 0.113 \\
OS (months) & 56.37 & 41.27 & 0.010 \\
\hline
\end{tabular}

In group B

\begin{tabular}{|llll|}
\hline Brain metastasis (OSI) & NO & YES & P value \\
\hline Total $n=53$ & $33(62.3 \%)$ & $20(37.7 \%)$ & \\
PFS (months) & 11.87 & 10.27 & 0.091 \\
OS (months) & NA & 67.10 & 0.340 \\
\hline
\end{tabular}

Brain Metastasis $(\mathrm{OSI})=$ brain metastasis was noted before osimertinib treatment.

Table 8. PFS and OS of the patients who received osimertinib treatment after previous chemotherapy (Group A) or immediately following treatment with another EGFR-TKI (Group B). L858R and Del 19 subgroup analysis. $(n=95)$ 


\begin{tabular}{|llll|}
\hline $\begin{array}{l}\text { Group } \\
\mathrm{n}=95\end{array}$ & $\begin{array}{l}\text { After Chemotherapy (Group A) } \\
(\mathrm{n}=42,44.2 \%)\end{array}$ & $\begin{array}{l}\text { After Another EGFR-TKI } \\
(\text { Group B }) \\
(\mathrm{n}=53,55.8 \%)\end{array}$ & P value \\
\hline L858R & $15(35.7 \%)$ & $26(49.1 \%)$ & \\
\hline Del 19 & $27(64.3 \%)$ & $27(50.9 \%)$ & \\
L858R $n=41$ & 15 & 26 & 0.3192 \\
PFS (months) & 12.5 & 9.0 & 0.994 \\
OS (months) & 66.53 & 67.10 & 0.950 \\
\hline Del 19 $\mathrm{n}=54$ & 27 & 27 & 0.232 \\
PFS (months) & 15.70 & 11.93 & \\
OS (months) & 56.37 & NA & 0.315 \\
\hline Total n=95 & 42 & 53 & 0.407 \\
PFS (months) & 13.17 & 10.83 & \\
OS (months) & 56.37 & NA & \\
\hline Data had exclude the double mutation with T790M if first biopsy. & \\
\hline PFS= median progression free survival, OS= median overall survival. & \\
\hline
\end{tabular}

\section{Supplementary Files}

This is a list of supplementary files associated with this preprint. Click to download.

- 202012090simertinibsequencytreamentsupplymentaryfinal.doc 